\title{
HISTORY OF NATIONAL MOVEMENT GAMES
}

\author{
Bahram Pulatovich Pardayev
}

Senior Lecturer, Institute Of Scientific And Methodological Support, Retraining And Advanced Training Of Physical Culture And Sports Specialists Under The Ministry Of Physical Culture And Sports Of The Republic Of Uzbekistan

\section{ABSTRACT}

This article discusses the history of the origins of the National Action Games. Information is provided on the period in which the history of the origin of action games, which are popular today, dates back to. The article is one of the tools for the successful implementation of mental, moral and physical education of students in physical education classes of general secondary schools.

KEYWORDS:- Play activities, games, sports games, folk games, child, social environment, community, elementary community, hunting, mental training, physical training, primitive games, post-hunt games, mental development, folk games, national games, movement games.

\section{INTRODUCTION}

Historically, hunting games have played an important role in the lives of primitive hunters. Some sources say they are held before the hunt, while others commented as post-hunt games. If we analyze this data in more depth, we can say that hunting games were held both before and after the hunt. The ancient games which primitive people played were in the role of preparation for the hunt. While playing those games they learnt how to hunt, how to catch the prey, how to mask themselves to trick the prey or how to make animals' sound and movements while hunting. It was during such games that young people were also taught to hunt. For this reason, by passing a specific school task, on the one hand, he helped to develop the skills of hunters, and on the other hand, he formed and developed the art of imitation in them.

The post-hunt games can be supposed to be played as a way to celebrate their successful hunting. As returning with the prey was a real feast, made it possible to rejoice, to celebrate in a whole team.

Every nation has a cultural heritage left over from past generations, and its treasures of cultural riches include folk games. Folk games are not an unusual phenomenon in terms of their origin and development, but an activity that is figuratively reflecting the life of the people, defined in a certain way and in harmony with the laws of social development.

Folk games are a unique genre of folk art and have a long history. They clearly reflect the social events at one stage or another in the development of society. 
CURRENT RESEARCH JOURNAL OF PEDAGOGICS 2(11): 197-202,

November 2021 DOI: https://doi.org/10.37547/pedagogics-crjp-02-11-36

ISSN 2767-3278

(C)2021 Master Journals

Crossref do: 81 Google

Accepted 25th November, 2021 \& Published 30 ${ }^{\text {th }}$ November, 2021

It is known that labor and other activities, including play, have a social character. Games originated at a historical stage when they became the basis for the emergence and development of people's work culture. Games are a product of social development. Each historical period contributes to the artistic mastery of the world: art seeks to reflect more fully and vividly the multifaceted events of social life, to a certain extent generalize the achievements of science, culture, politics, ethics and economics. In the early stages of the development of society, the use of folk games for educational purposes was associated with productive labor. The content and character of folk games stem from the socioeconomic conditions of life and the mental characteristics of the peoples that make up the composition, the character of which is influenced by the direction, ideology, lifestyle of the educational system.

In considering the issues related to the gradual development of folk games in the process of historical development and their use for educational purposes, it is necessary to take into account the specific aspects of folk games. The games were created by the people and figuratively reflect the events and happenings of people's daily lives, embodying their life impressions, observations, experiences and feelings, combining words, music and dance. For example, a characteristic feature of raising children in the primitive system was to acquaint them with the customs, traditions, history of the tribe, as well as folklore: legends, songs and dances. In primitive society, holiday-religious ceremonies, known as adding young people to the ranks of adults, were common. These are peculiar games and competitions, the content of which is labor activity, tribal customs, traditions, folklore. In such games, the young men had to demonstrate their skillful use of weapons, their ability to follow religious customs satisfactorily, and their knowledge of the sacred legends of the tribe. Dances were also performed in the ceremonies, in which primitive people expressed the events of their lives, their successes and failures, their joys and sorrows.

The hunting of wild animals by primitive people and their desire to subdue them necessitated the creation of hunting events and their creative display. Exploring the origins of play and art, D. U. Elkonin said, "Primitive people expressed hunting, war events, and other serious activities in games." He concluded that playing a failure in the hunt helped them identify the mistakes they made and the reasons for their failure.

The increasing development of the productive forces, the improvement of the tools of labor, in the last stages of the primitive collective system, led to the inability of children to use these tools of labor in ordinary life and productive labor as before. As a result, labor toys resembling children's toys began to be made. The means of children's play - toys may have come into being in this way. According to E. A. Arkin, they are 'ancient toys', a product of historical development, as well as an expression of the history of the weapons and means of worship of human labor. Thus, the development of the game during the primitive community system was not only a "religious luxury", but also a desire to understand the surrounding events, to strengthen knowledge about it, to learn to "create according to the image and like nature."

Each nation has its own national games, which are based on the traditions of the people, the culture and way of life of the nations. Folk games are one of the manifestations of spiritual culture.

They reflect the traditions of ethnic history, social relations, some elements of ideology and beliefs, moral and aesthetic norms. Folk games reflect the national characteristics of the country, the behavior, habits, labor processes, geographical conditions of adults. Accordingly, the Uzbek folk games should be considered as 
CURRENT RESEARCH JOURNAL OF PEDAGOGICS 2(11): 197-202,

November 2021 DOI: https://doi.org/10.37547/pedagogics-crjp-02-11-36

ISSN 2767-3278

(C)2021 Master Journals

Crossref do: 81 Google

Accepted 25th November, 2021 \& Published 30 ${ }^{\text {th }}$ November, 2021

one of the sources of studying the moral and aesthetic history, culture and relations of the people with other nations. In studying the history of Uzbek folk dances, it is very important to cover the stages of development of the national spiritual culture.

Uzbek folk games are the product of the collective creativity of the Uzbek people, created and maintained by a wide range of people.

Games have been developed over the centuries as a necessary element of life and social life of many generations of the Uzbek people and have fulfilled various social functions at each historical stage of development. Uzbek folk dances embody the creative power, material and spiritual riches of history, reflecting the historical experience of knowing and mastering the surrounding reality. Uzbek folk games are practical by nature. They clearly show the originality of folk art culture, its national features. At the heart of the national character of these games is the cultural richness and great heritage of the people. Folklore, in particular, can serve as a source for genres such as his epics and historical narratives. Themes of polygamous content can shed light on tribal customs, ancient customs, labor activities, or culture. The forgotten pleas, bytes and counts of the people continue only in the children's folk games. Uzbek folk games and some sports, which are played as a group, are based on games of ancient tribes.

Uzbek folk games originated in ancient times before our era. This is confirmed by archeological excavations and ethnographic materials of the ancient Roman writer Elian. Because they have information that games are very common in the Saks tribe and they are a favorite custom of the people. According to him, the boys of the Saks tribe received the right to marry the girls they defeated in these games.

From ancient times the peoples of Central Asia have had such physical exercises as wrestling, archery, and horseback riding. The Greek historian Herodotus wrote of the snipers of the Saxon tribe, who lived side by side with the Khorezmians: The Roman writer Klament Alexandriusky (second century BC) wrote of the women of the Saka tribe:

National folk dances originated in the squares as ancient spectacles several hundred years ago. This is confirmed by archeological excavations and ethnographic materials of the ancient Roman writer Elian. Because they have information that games were common in the Saks tribe and that they were a favorite custom of the people. He testified that the boys of the Saks tribe had the right to marry the girls they had defeated in these games.

National folk games originated in the squares centuries ago as ancient spectacles. The history of their emergence is associated with the development of sports, theater, dance and circus arts in our region. The content of folk games is very rich, colorful and very diverse, and has a certain historical character. They embodied the best traditions of folk ceremonies and performances, enriched the national culture with its unique originality and features, uniting the folk traditions of their generations.

Among the national folk games, the ancient art of "dorboz" and "simvoz" was especially distinguished. In the past, the "game of dor" was very popular. It can be said that public and local holidays, seasonal markets did not pass without them. In Registan, "dors" ( a long rope between the top of two strong wooden posts on which dorboz walked and entertained public) were built on in Chorsu market squares. The sound of trumpets and drums signaled the beginning of the show. As people gathered, the games began. The spectators watched with excitement the bold movements of the doorman playing on a high stretched rope.

Once upon a time, a wooden foot game was 
CURRENT RESEARCH JOURNAL OF PEDAGOGICS 2(11): 197-202,

November 2021 DOI: https://doi.org/10.37547/pedagogics-crjp-02-11-36

ISSN 2767-3278

(C)2021 Master Journals

Crossref do: 81 Google

Accepted 25th November, 2021 \& Published 30 ${ }^{\text {th }}$ November, 2021

widespread in our area. The woodpeckers ran, jumped, danced, performed melodies on national instruments such as trumpets and horns, and put on spectacular performances. There is a lot of information about this in "Boburnoma". "Stick game" is widespread in Khorezm.

The study of the traditional life of the Uzbek people shows that the territory of the presentday Republic of Uzbekistan was once inhabited mainly by nomadic and semi-nomadic peoples. Their main occupation was animal husbandry. Not only semi-sedentary but also sedentary farmers were engaged in cattle breeding. Farmers used cattle to plow the land, grind wheat, and draw water from rivers and wells. Livestock was also used by traders and artisans. Due to this, a number of Uzbek folk games such as "Podachi", "Lame wolf and sheep", "Goats and shepherds", "White camel", "The wolf came" originated.

Among our people there are such interesting dances on the theme of animals and birds as "Pigeon Game", "Baby", "Yumronkoziq", "Horse Game". Also among the Uzbeks are "Karnaymi, surnay", "Nina, rope and knot", "Tapir-topur slate", "Pumpkin planting", "Rooster fight", "Rooster and chicken". Games such as "Run, baby, the bird has come", "White poplar-blue poplar" were also popular.

National folk games originated in very ancient times, changing their content at each historical stage of development and performing various social functions.

Traditions, sciences, including national games, are connected with the life of our nation and passed down from generation to generation. The knowledge and experiences acquired by generations have been tested in practical life, reinforced and improved by subsequent generations. Their content has been updated by each generation, the stages of development of society. Children played folk national games played by adults at that stage of community development. Many national games have been passed down from fathers and grandfathers to children and grandchildren.

In the national games of the people, the social life, labor activity and lifestyle of the people were reflected in specific forms. They have very rich feelings and experiences, love for their homeland, dreams of protection.

National folk games can be classified according to their content as follows:

\section{Dramatized games}

A. Vital (historical-vital, cultural-vital, professional-vital).

B. Funny games.

V. Song and dance games.

II. Meaningful role-playing games

A. Meaningful-moving.

B. Sports Games.

III. Creative games

Analyzing the historical origins of the national folk games, we conclude that the dramatic games are based on the ancient folk art of "puppetry", which became the basis of the Uzbek puppet theater. possible.

The puppet, which represents a particular artistic image, reflects the historical and social events in the life of the country and its people, the beauty and shortcomings of the practical manifestations of cultural and everyday changes.

Drama plays are often accompanied by music and dances of the heroes. The children observed the lives of adults, their work activities, natural phenomena, and participated in folk performances, describing in their games what they had built. Random depictions of life were the basis for meaning-role, meaning-action, and sports games. 
CURRENT RESEARCH JOURNAL OF PEDAGOGICS 2(11): 197-202,

November 2021 DOI: https://doi.org/10.37547/pedagogics-crjp-02-11-36

ISSN 2767-3278

(C)2021 Master Journals

Crossref do: 81 Google

Accepted 25th November, 2021 \& Published 30 ${ }^{\text {th }}$ November, 2021

The dramatized games are based on Uzbek folk tales and legends. The purpose of such games is to play fairy tales and legends. Drama games are very bright in terms of their content. Participants are individuals who embody all the features of an artistic image, whether it is an animal or a bird, or a human being. In this case, the animal world also has human characteristics.

The content of the story, the struggle between the participants, interests the child and captivates his heart.

Life games are games that illuminate the history, life, culture and labor activities of our people.

Funny games are games based on the skillful illumination of characters and characters, light laughter over certain negative behaviors in people. Such games are organized to "punish" the culprits, while at the same time introducing unexpected and random elements. They reflect the history of the culture of our people, the culture of humor and clowning.

Song and dance games are a unique genre of folk culture, based on folklore as a propagandist of the national oral, theatrical and musical traditions of our people. They represent the spiritual wealth and aesthetic taste of our people.

Meaningful role-playing and meaningful - action games are attractive and interesting, introducing the perfect content and the qualities of different worlds, nature, some things. The essence and significance of the games in this group are different.

Creative games include:

A. Games created by students based on Uzbek folk tales and legends.

B. Voluntary and thematic games aimed at aesthetic purposes.

V. Purposeful games are games in which students create different beginnings and endings, the outcome of which is known.
G. Games in which poetry weaving, singing, dancing, gestures, imitation, etc. are performed to activate students 'creative abilities.

D. Games for visual creativity, doing what is needed for games.

Folk dances refer to life events and express them in artistic images that are fascinating with their diversity, richness and diversity.

\section{REFERENCES}

1. F.Khojaev and others "People's National Games" Tashkent-2001

2. F.Khojaev "Moving games for children" Tashkent-2016

3. F.Khojaev "National action games for high school students" Tashkent-2015

4. F.Khojaev and others "Moving games and methods of teaching" Cholpon Publishing House Tashkent-2016

5. F.Khojaev and others "National action games and relays" Tashkent-2017

6. F.Khojaev "Sports and movement games and methods of teaching" (Moving games) Tashkent-2008

7. Ye.V. Kuzmicheva "Podvijnye igry dlya detey srednego i starshego shkolnogo vozrasta" M2008 "Fizicheskaya kultura"

8. Abdullaeva, B., Babarakhimova, B., \& Pardayev, B. P. (2020). USING

9. INFORMATION AND COMMUNICATION TECHNOLOGIES IN TEACHING PROCESS OF VARIOUS PRIMARY SCHOOL. European Journal of Research and Reflection in Educational Sciences Vol, 8 (10).

10. Pardayev BP METHODOLOGY OF TEACHING TECHNIQUES OF ACROBATIC EXERCISES Current research journal of pedagogics 2 (8): 101-109, August 2021 
CURRENT RESEARCH JOURNAL OF PEDAGOGICS 2(11): 197-202,

November 2021 DOI: https://doi.org/10.37547/pedagogics-crjp-02-11-36

ISSN 2767-3278

(C)2021 Master Journals

Crossref dof 81 Google

Accepted 25th November, 2021 \& Published 30th November, 2021

11. Pardayev BP APPLICATION OF NATIONAL MOVEMENT GAMES IN PHYSICAL EDUCATION CLASSES Current research journal of pedagogics 2 (8): 96-100, August 2021 